Article

\title{
A Global ETCCDI-Based Precipitation Climatology from Satellite and Rain Gauge Measurements
}

\author{
Felix Dietzsch * Axel Andersson ${ }^{\dagger}$, Markus Ziese, Marc Schröder, Kristin Raykova, \\ Kirstin Schamm and Andreas Becker \\ Deutscher Wetterdienst, Frankfurter Straße 135, 63067 Offenbach (Main), Germany; \\ axel.andersson@dwd.de (A.A.); markus.ziese@dwd.de (M.Z.); marc.schroeder@dwd.de (M.S.); \\ kristin.raykova@dwd.de (K.R.); kirstin@schamm.de (K.S.); andreas.becker@dwd.de (A.B.) \\ * Correspondence: felix.dietzsch@dwd.de; Tel.: +49-69-8062-2087 \\ + Current address: Deutscher Wetterdienst, Bernhard-Nocht-Straße 76, 20359 Hamburg, Germany.
}

Academic Editor: Yang Zhang

Received: 25 November 2016 ; Accepted: 4 February 2017; Published: 16 February 2017

\begin{abstract}
Precipitation is still one of the most complex climate variables to observe, to understand, and to handle within climate monitoring and climate analysis as well as to simulate in numerical weather prediction and climate models. Especially over ocean, less is known about precipitation than over land due to the sparsity of in situ observations. Here, we introduce and discuss a global Expert Team on Climate Change and Indices (ETCCDI)-based precipitation climatology. The basis for computation of this climatology is the global precipitation dataset Daily Precipitation Analysis for Climate Prediction (DAPACLIP) which combines in situ observation data over land and satellite-based remote sensing data over ocean in daily temporal resolution, namely data from the Global Precipitation Climatology Centre (GPCC) and the Hamburg Ocean Atmosphere Parameters and Fluxes from Satellite Data (HOAPS) dataset. The DAPACLIP dataset spans the period 1988-2008 and thus the global ETCCDI-based precipitation climatology covers 21 years in total. Regional aspects of the climatology are also discussed with focus on Europe and the monsoon region of south-east Asia. To our knowledge, this is the first presentation and discussion of an ETCCDI-based precipitation climatology on a global scale.
\end{abstract}

Keywords: precipitation; satellite; climatology; ETCCDI; rain gauge; global

\section{Introduction}

While precipitation is one of the most important climate variables, it is also one of the most complex variables regarding global distribution and variability. This makes it difficult to handle, e.g., in climate models. The new global precipitation dataset Daily Precipitation Analysis for Climate Prediction (DAPACLIP) which combines in situ and satellite-based remote sensing data is introduced. The main purpose of the development of the dataset is the evaluation of decadal climate predictions of the Mittelfristige Klimaprognosen (MiKlip) project framework [1]. In this paper, the global and regional aspects of DAPACLIP are evaluated. A special emphasis is put on the Expert Team on Climate Change and detection indices (ETCCDI) that are used for the evaluation. Climatological features related to precipitation and based on the ETCCDI are discussed and certain features for Europe and the monsoon region of south-east Asia are emphasized. Results from this work will form the basic evaluation of the MiKlip decadal prediction system.

A lot of effort has been put into the development of remote sensing-based regional and global precipitation datasets in the past years and decades. Frequently used datasets are the Global Precipitation Climatology Project (GPCP) and products from the Tropical Rainfall Measurement Mission (TRMM). GPCP provides gridded datasets on a monthly and a daily basis. It is a combined 
product from various satellite-based sources, such as the Special Sensor Microwave Imager (SSM/I) and Special Sensor Microwave Imager Sounder (SSMIS), infrared (IR) imagers, and Television and Infrared Observation Satellite (TIROS)-based Observation Vertical Sounder (TOVS) precipitation analysis, additional gauge data, and the Outgoing Longwave Radiation (OLR) precipitation index. Details can be found in [2-4]. A large variety of Tropical Rainfall Measurement Mission (TRMM)-based precipitation products are available, which partly additionally include data from SSM/I, Advanced Microwave Scanning Radiometer-Earth Observation System (AMSR-E), Advanced Microwave Sounding Unit-B (AMSU-B) and IR observations from geostationary platforms. TRMM products do not cover the whole globe, but latitudes up to $60^{\circ}$, dependent on the specific dataset. Details about TRMM data are explained in, e.g., [5].

The main difference between these precipitation datasets and the presented DAPACLIP dataset is that the DAPACLIP dataset combines gauge and satellite data by keeping the individual dataset characteristics and in particular by not changing the uncertainty of the individual datasets. Other datasets use satellite retrievals also over land, which are often calibrated by using gauge data.

ETCCDIs play an important role in the assessment of climate extremes. This is well addressed in [6], which describes the progress over the last decades as well as for the Intergovernmental Panel On Climate Change (IPCC) AR5 report. Also, the indices are used for intercomparisons of hindcasts from CMIP3 and CMIP5, reanalysis data and observational data [7] as well as for CMIP climate projections of CMIP3 and CMIP5 [8]. In [9], it is stated that satellite-based climate datasets now become relevant for climate extreme detection and attribution because their temporal coverage starts to reach sufficient length to be of value for climate analysis. This emphasizes one of the values of the DAPACLIP dataset presented in this study. In addition, precipitation extremes and their distribution were analyzed using ETCCDI and gridded rain gauge data from the GPCC [10]. All of these analyses were carried out using ETCCDI indices only over land and not globally.

After a short introduction of the DAPACLIP dataset and the ETCCDI indices, the ETCCDI-based precipitation climatology is presented and discussed, first on a global scale and then for Europe and the Asian monsoon region.

\section{Data and Methodology}

This section describes the data, the processing and the methods used for the resulting dataset. For the global dataset, a combination from interpolated and gridded station-based rain gauge measurements is used over land, and a rain rate retrieval algorithm and gridding procedure for satellite-based passive microwave imagers is used over ocean. Both separate datasets are then merged to a single precipitation dataset. The dataset includes the years from 1988 to 2008. It is provided in three different spatial resolutions of $0.5^{\circ}, 1^{\circ}$ and $2.5^{\circ}$. The half degree version is only available for the European domain $\left(30^{\circ} \mathrm{N}\right.$ to $80^{\circ} \mathrm{N}$ and $30^{\circ} \mathrm{W}$ to $\left.65^{\circ} \mathrm{E}\right)$. Otherwise, the whole global scale is covered. For the DAPACLIP dataset and the derived climatology, the use of ETCCDI indices is elucidated.

\subsection{Rain Gauge Measurements}

The GPCC at Deutscher Wetterdienst (DWD) provides daily precipitation products created from station-based rain gauge measurement data. Data are mainly received from national meteorological and hydrological services. Other sources are used as well, e.g., from local authorities, global and regional data collections, and near real-time World Meteorological Organisation Global Telecommunicataion System (WMO-GTS) CLIMAT and SYNOP data. At first, the retrieved station data are checked for quality, e.g., common problems are coding errors in SYNOP data, different latin transcriptions of station names, or transmission errors. Figure 1 shows the number of available stations for the dataset split up into the different sources. The total number of used stations lies approximately between 30,000 in 1988 and 25,000 in 2008. 


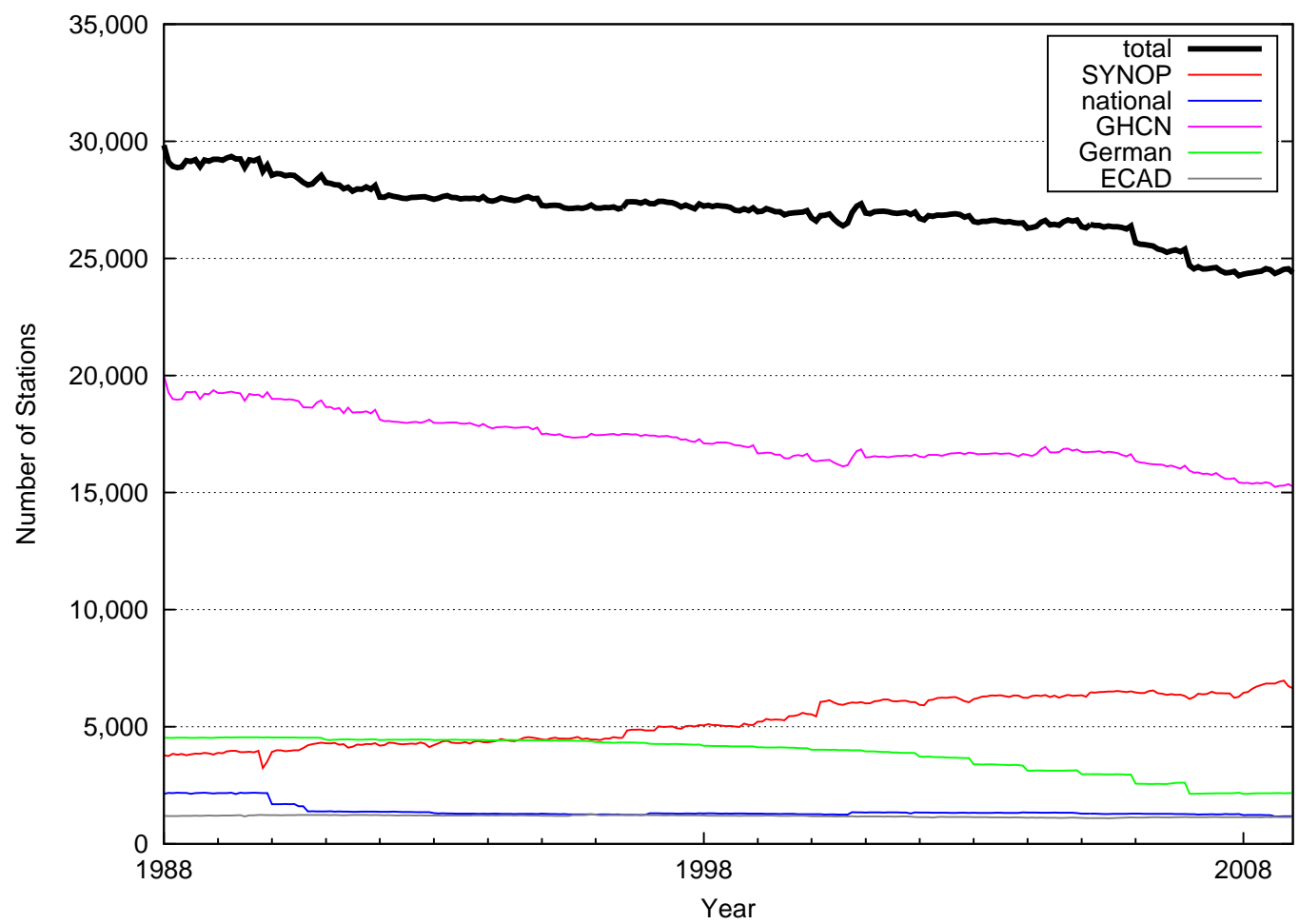

Figure 1. Temporal distribution of used land-surface stations. "SYNOP" are stations distributed via the World Meteorological Organisation Global Telecommunication System (WMO-GTS) , "National” are data provided by national meteorological and/or hydrological services, "GHCN" are data from the Global Historical Climatology Network [11], “German” are stations operated by Deutscher Wetterdienst (DWD) , "ECAD" are data from the European Climate Data and Assessment [12], and "Total" is the set union of all available stations at one date (multiple stations counted only once).

For the DAPACLIP dataset used here, the GPCC developed a "Full Data Daily" product [13]. It consists of daily precipitation sums that are interpolated onto a regular grid. Different interpolation schemes have been investigated in order to find the best performing one: inverse distance weighting, SPHEREMAP (described in [14]), ordinary kriging with different corellogram settings and the mean of the nearest precipitation measurements. Details on kriging are described in $[15,16]$. To find the optimal interpolation method, a "leave-one-out" approach was applied to all stations. All schemes were tested with interpolation of precipitation totals and relative anomalies. Ordinary block kriging of relative anomalies was chosen as the best performing interpolation method and was used for the gauge data. The background data for the relative anomaly interpolation were taken from the GPCC Full Data Monthly V7 product $[17,18]$. Verification results on the GPCC climatology compared to other datasets are described in [17]. Uncertainty information is provided with the gauge data. The uncertainty is influenced by station density, precipitation amount, precipitation phase and orography. For the Full Data Daily product, the uncertainty information is split into two components. The kriging interpolation error contains biases caused by the spatial distribution of stations and the grid size. The absolute uncertainty contains the standard deviation of the measured precipitation [13,19]. Figure 2 provides insight into the available features of the GPCC daily precipitation product and gives an impression of data quality and uncertainty. 
GPCC Full Data Daily $1^{\circ}$ for 29 June 2008
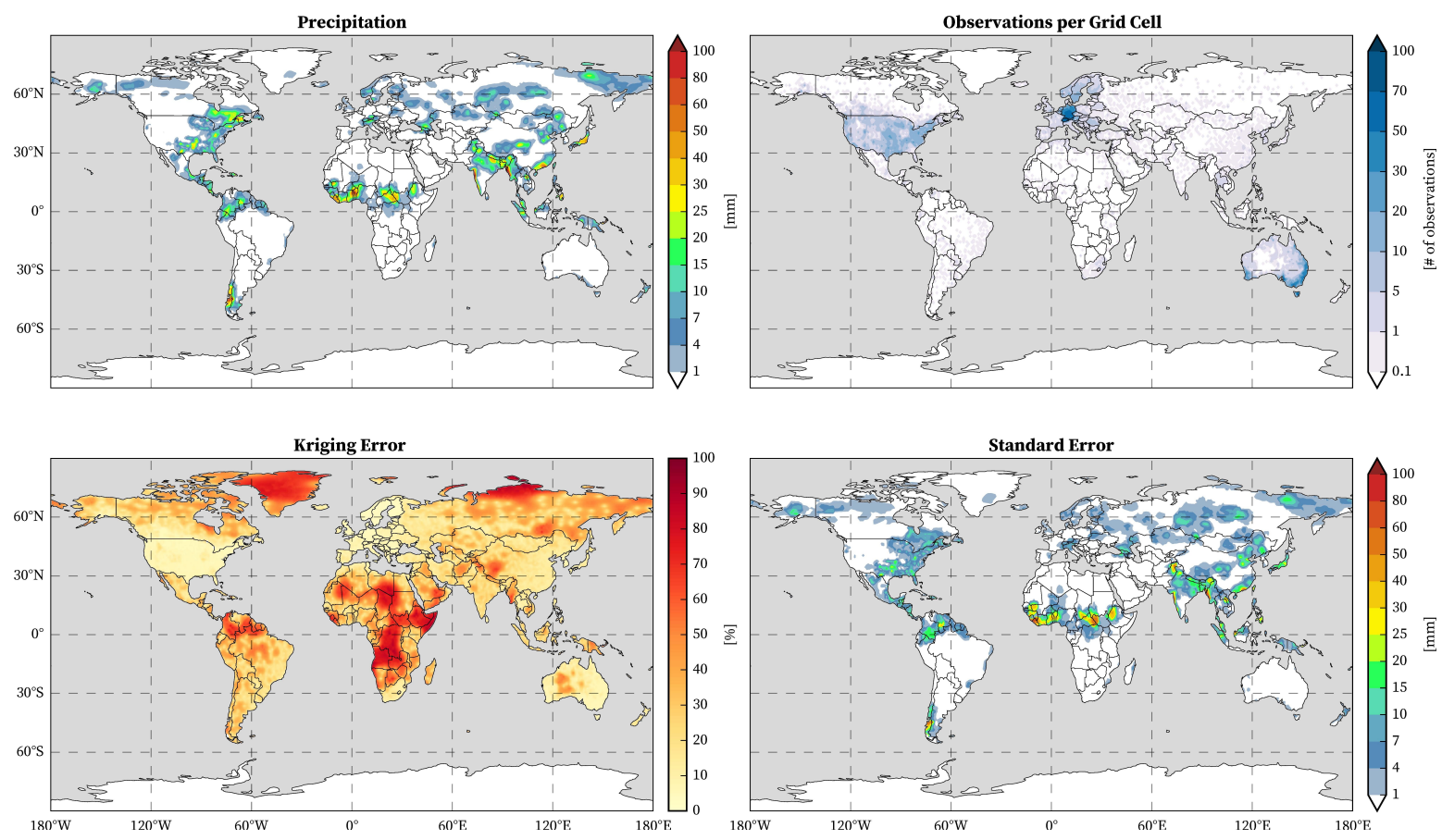

Figure 2. Example of the features of the Global Precipitation Climatology Centre (GPCC) daily precipitation product for 29 June, 2008. (adapted from [13]). Top left: estimated amount of precipitation in $\mathrm{mm} \cdot \mathrm{d}^{-1}$. Top right: distribution of precipitation measurement stations. Bottom left: kriging error in $\%$. Bottom right: standard deviation according to the method of [19] in $\mathrm{mm} \cdot \mathrm{d}^{-1}$.

\subsection{Satellite Remote Sensing}

A statistical neuronal network algorithm is used to derive precipitation data from satellite-based passive microwave imagers. The data that have been used here are based on the HOAPS-3.2 dataset [20-23]. This version of HOAPS is provided and distributed by the Satellite Application Facility on Climate Monitoring (CM SAF). The HOAPS dataset itself uses brightness temperatures (BT) from SSM/I. This is explained in detail in [22,24]. The algorithm is applied over ice-free ocean and $50 \mathrm{~km}$ off coasts. Figure 3 shows a spatial map of the HOAPS-3.2 precipitation climatology. Verification results of the HOAPS dataset can be found in [22,23], and references therein. For the global precipitation product, HOAPS-3.2 was enhanced by using additional TRMM microwave imager BT data available for 1997 and later. This increases the temporal sampling per region due to the additional instrument overpasses for the respective time range. Thus, the HOAPS rain rate retrieval algorithm was adapted accordingly to allow the processing of TMI data.

After processing the BTs, the rain rates are accumulated to daily precipitation totals and gridded by calculating the Gaussian mean for all pixel values that belong to a certain grid cell. The Gaussian standard error is given as an uncertainty measure.

\subsection{Data Merging}

After separate processing of precipitation data over land (GPCC) and ocean (HOAPS), both datasets are merged by filling the global grid with values from each dataset. Grid cells where data from both land and ocean are available are filled with ocean values. The maximum fraction of land in grid cells with values from both datasets is $5 \%$. Hence it seems reasonable to neglect the GPCC data here. Remaining grid cells are filled with interpolated values from land and ocean data. In this way, data from both GPCC and HOAPS find entrance into corresponding grid cell values. This leads simultaneously to a smooth gradient at the edge of land and ocean data. Figure 4 shows 
an exemplary day with global precipitation over land and ocean merged from both datasets. The merged GPCC and HOAPS data record is referenced (DOIs 10.5676/DWD_CDC/HOGP_050/V001, 10.5676/DWD_CDC/HOGP_100/V001, and 10.5676/DWD_CDC/HOGP_250/V001, [25-27]) and is available via the GPCC webpage [28].

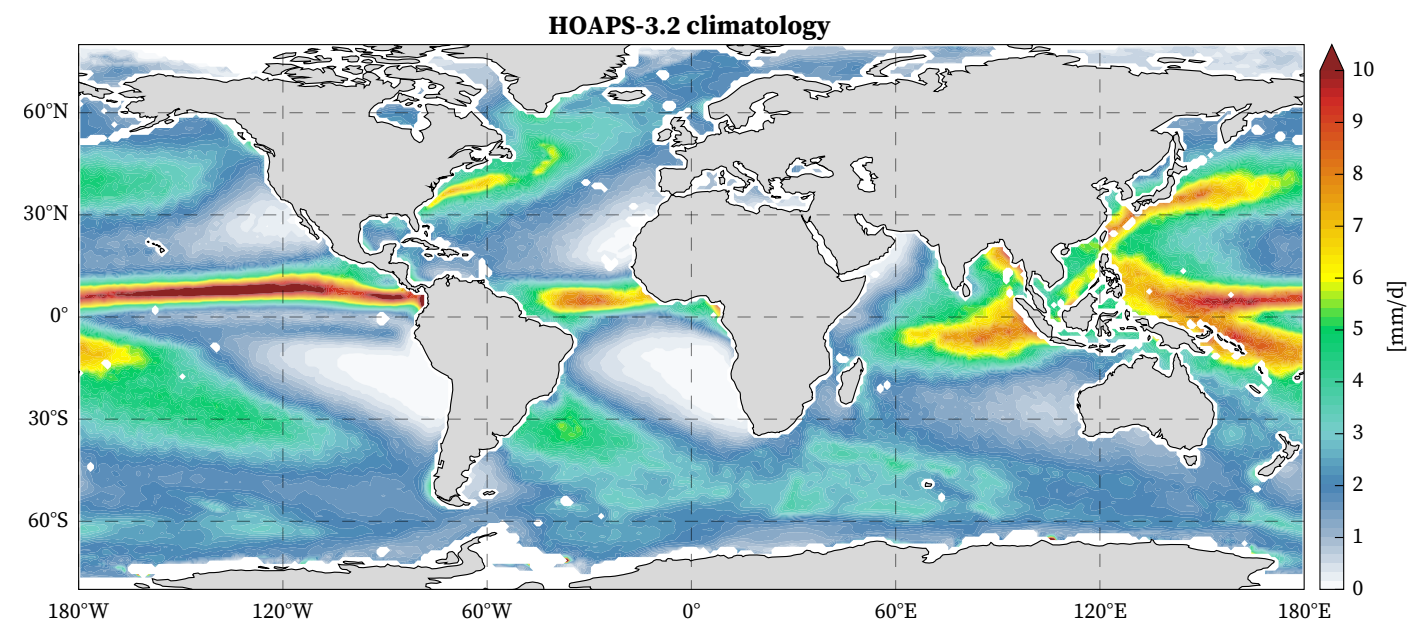

Figure 3. Climatological mean field of Hamburg Ocean Atmosphere Parameters and Fluxes from Satellite data version 3.2 (HOAPS-3.2) precipitation for the years 1988 to 2008 (adapted from [22]).

\section{DAPACLIP}

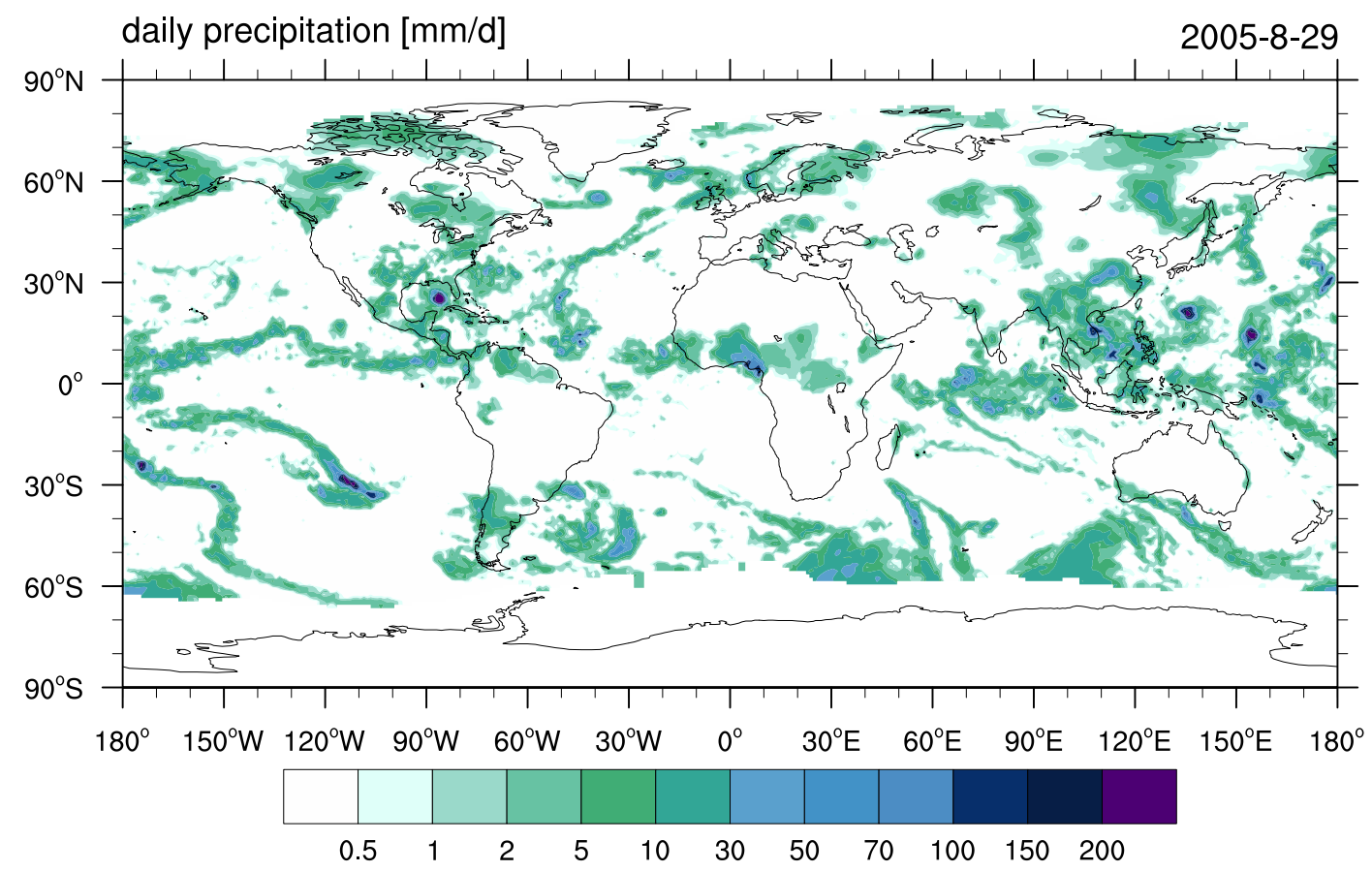

Figure 4. Example of the merged Daily Precipitation Analysis for Climate Prediction dataset (DAPACLIP) from land and ocean data for 29 August, 2005. Remarkable features from distinct events can be seen, for example the precipitation pattern of hurricane Katrina at the Gulf of Mexico and several tropical storms in the western Pacific Ocean. 


\subsection{ETCCDI}

The ETCCDI provides indices and datasets for the assessment of climate variability and change [29]. Here, a subset of these indices is used for the determination of global precipitation characteristics. The selected indices are listed in Table 1.

An alternative definition of the 95th (r95p) and 99th percentile (r99p) indices is used, since the original definition of each of these indices asks for another background climatology, and then gives the precipitation sum of all days that exceed the percentile threshold. This is more useful when it comes to comparisons, e.g., between models and observation data, or trend detection. Here, we use the percentile values themselves, since these indices illustrate the precipitation climatology in a better way. The Simple Daily Intensity Index (sdii) is the mean precipitation amount that is registered on wet days. More detailed descriptions of the indices can be found in [30].

Table 1. List of used Expert Team on Climate Change and Detection precipitation indices (ETCCDI). Wet days are defined by precipitation $\geq 1 \mathrm{~mm} \cdot$ day $^{-1}[30,31]$.

\begin{tabular}{lll}
\hline Index & Description & Unit \\
\hline cdd & Maximum number of Consecutive Dry Days & days \\
cwd & Maximum number of Consecutive Wet Days & days \\
r10 & Number of days with more than 10 mm of precipitation & days \\
r20 & Number of days with more than 20 mm of precipitation & days \\
r95p & 95th percentile of the daily precipitation amount & $\mathrm{mm} \cdot \mathrm{day}^{-1}$ \\
r99p & 99th percentile of the daily precipitation amount & $\mathrm{mm} \cdot \mathrm{day}^{-1}$ \\
rx1 & Maximum precipitation sum of one day & $\mathrm{mm}$ \\
rx5 & Maximum precipitation sum of five consecutive days & $\mathrm{mm}$ \\
sdii & Simple Daily Intensity Index & $\mathrm{mm} \cdot \mathrm{day}^{-1}$ \\
\hline
\end{tabular}

\section{Results}

\subsection{Global Climatology}

Figure 5 shows the ETCCDI values for the DAPACLIP dataset on a one degree regular longitude/latitude global grid. The consecutive dry days index (cdd) values are shown in panel (a). Here, we find the longest dry spells in the Saharan desert, the Atacama desert, the Gobi desert and the Californian peninsula. The most extreme value is found in the eastern Saharan desert, where the dry spell duration matches the complete dataset time span from 1988 to 2008; Panel (b) shows the consecutive wet days index (cwd). The largest values appear in the monsoon-influenced and tropical regions. We also find characteristically increased values along the west coast of Europe and North America, where wet spell durations exceed one month. Wet spells of more than three months occur on the tropical and monsoon regions, with maximum values of more than nine months along the Pacific coast of Colombia; Panel (c) shows the r95p index. The patterns here correspond well with the annual mean precipitation, as shown in Figure 2 in [2]. In general, maximum values are found along the Intertropical Convergence Zone (ITCZ), e.g., over the central Pacific Ocean, the central Atlantic Ocean, and the Indian Ocean. Also, the typical extra-tropical cyclone tracks can be seen in the north east Pacific off the coast of Taiwan and Japan, and in the northern Atlantic ocean along with increased percentile values at the coast of north-west America and at the European west coasts especially for Norway. At the U.S. east coast, we find increased percentile values, since it is a typical event for this region, that tropical storm systems and hurricanes turn northwards and convert into extra-tropical low pressure systems on their way over the Atlantic. We also find higher percentiles for the west coast of New Zealand. In the monsoon regions of Southeast Asia, percentile values of $50 \mathrm{~mm} \cdot$ day $^{-1}$ are exceeded; Panel (d) shows the r99p index. While the r95p values reach $80 \mathrm{~mm} \cdot$ day $^{-1}, \mathrm{r} 99 \mathrm{p}$ exceeds $200 \mathrm{~mm} \cdot \mathrm{day}^{-1}$. The largest precipitation amounts are found in the western Pacific ocean, the Indian ocean, along the equator, and along the American east coast with 
more than $60 \mathrm{~mm} \cdot \mathrm{day}^{-1}$. Over land, the 99th percentile values are smaller in general, but again we find certain regions among coastal areas with large extreme precipitation values (e.g., Norway, Galicia, Canadian west coast, southern New Zealand); Panel (e) shows the heavy precipitation index $\mathrm{r} 10$, which is here defined as the mean of number of days per year, where precipitation amounts of $\geq 10 \mathrm{~mm} \cdot \mathrm{d}^{-1}$ occur. Here, we find local maxima along the equator with values from 50 to 90 days. The largest values are found over land in tropical and monsoon regions in South America and Southeast Asia with more than 90 days per year. The global maximum is found at the Colombian west coast with a value of 227 days; Panel (f) shows the same index for days with more than $20 \mathrm{~mm} \cdot \mathrm{d}^{-1}$ of precipitation (r20). The distribution patterns are very similar compared to the preceding index. Here, the global maximum value is 130 days at the Colombian west coast; Panel (g) shows the maximum one day precipitation index ( $r x 1)$. The values over ocean are consistently larger than over land and can reach $800 \mathrm{~mm}$ for a single day. The maximum values are significantly lower over land, but can reach $100 \mathrm{~mm}$. These values are found predominantly in the tropics and subtropics; Panel (h) shows the maximum five day precipitation index (rx5). Similar to the rx1 index, the largest values are found over ocean with local maxima of up to $2000 \mathrm{~mm} \cdot \mathrm{d}^{-1}$ over the Pacific and Indian ocean. These values are likely to be caused by certain tropical storm events. Over land, five day sums between 100 and $400 \mathrm{~mm}$ seem to be characteristic, except for the drier continental climate regions, where the extreme five day precipitation sums are lower (50 mm or less); Panel (i) shows the simple daily intensity index (sdii). Here, we find global maximum values along the ITCZ with values from 12 to $18 \mathrm{~mm} \cdot \mathrm{d}^{-1}$. Similar values occur in the already discussed tropical storm regions. The largest values are found again on coastal edges in the tropics and monsoon regions (Western Ghats, Bay of Bengal, Andaman Sea) with values up to $3 \mathrm{~mm} \cdot \mathrm{d}^{-1}$. Large values also occur at the Colombian west coast, Japanese south coast, southern Atlantic and Pacific ocean, the West African coast, and the U.S. east coast.

\subsection{Europe}

Figure 6 shows ETCCDI indices for the European domain from $30^{\circ} \mathrm{W}$ to $65^{\circ} \mathrm{E}$ and $30^{\circ} \mathrm{N}$ to $80^{\circ} \mathrm{N}$ at a higher spatial resolution of $0.5^{\circ}$. Indices with interesting features were selected. Panel (a) shows the cwd index. The maximum value of more than three months is located at the northwest of the Faroese islands. Values of more than two months are found at the northwest coast of Scotland. Wet spells of more than one month are found over larger areas, such as the Norwegian coast, the south of Iceland, along the European west coasts of Denmark, Germany, Ireland, Wales, but also in central Ukraine; Panel (b) shows the $\mathrm{r} 95 \mathrm{p}$ index. We mostly find values of less than $10 \mathrm{~mm} \cdot \mathrm{d}^{-1}$ especially in continental climate zones. Larger values occur at the southwestern coast of Norway with up to $45 \mathrm{~mm} \cdot \mathrm{d}^{-1}$. Large values also occur along the southwestern coast of Turkey with up to $60 \mathrm{~mm} \cdot \mathrm{d}^{-1}$. A further maximum is found along the Adriatic coast of Slovenia and Croatia with up to $45 \mathrm{~mm} \cdot \mathrm{d}^{-1}$. Over the Atlantic Ocean, single peaks of percentile precipitation amounts are found, and which are distributed heterogeneously. We assume these values to be signatures from extra-tropical cyclones. The distribution and intensity is a matter of further discussion; Panel (c) shows the heavy precipitation index r10. Here, regions with a larger number of significant precipitation events are emphasized well. Along the Norwegian coast, we find up to 120 days per year with more than $10 \mathrm{~mm}$ of precipitation on average, which is approximately every third day of the year. A similar value is also shown for a pixel at the Faroese islands. Values of up to 90 days per year occur at southern Iceland, Scotland, southwestern Ireland, and the northeastern Turkish coast. The index has smaller values in the southwestern Mediterranean region indicating that there are fewer events of heavy precipitation, but as shown in panel (b), extreme events on daily scale are present in this region. Local spots over land with an increased number of heavy precipitation events are found in Galicia, the Alps, and the Adriatic coast with up to 70 days per year. Over the Atlantic Ocean, the number of days with heavy precipitation exceeds values of 50 days per year on average, too. All the observed patterns of panels $(\mathrm{a}-\mathrm{c})$ are also related to positive and negative North Atlantic Oscillation (NAO) events. The precipitation correlates well with positive NAO events in north and northwest Europe, while it is anti-correlated for negative NAO events in 
southern Europe, especially for the Adriatic coast and the southwestern Turkish coast. Panel (d) shows the rx1 index. Over land, maximum values between 100 and $200 \mathrm{~mm} \cdot \mathrm{d}^{-1}$ occur. These values are reached in Norway, the Alps, the French Mediterranean region, the German Ore Mountains, and the Adriatic coast. It is possible to backtrack some of these values to single events. For example, in August 2002, a precipitation amount of $312 \mathrm{~mm} \cdot \mathrm{d}^{-1}$ was measured at the station of Zinnwald-Georgenfeld in the German Ore mountains due to a Vb-track low [32]. Because of the grid interpolation, that value does not appear in this climatology as such. The percentile values over ocean are generally larger than over land. The maximum values are found in the Atlantic ocean with up to $600 \mathrm{~mm} \cdot \mathrm{d}^{-1}$ and the Mediterranean Sea with up to $400 \mathrm{~mm} \cdot \mathrm{d}^{-1}$.

\subsection{Monsoon Asia}

Figure 7 shows selected ETCCDI indices for the Monsoon Asia region, which is here defined from $60^{\circ} \mathrm{E}$ to $180^{\circ} \mathrm{E}$ and from $15^{\circ} \mathrm{S}$ to $55^{\circ} \mathrm{N}$. Here, cdd, cwd, the number of days of the r10 index, and the sdii are shown. Typical monsoon characteristics can be identified for the regions, where both dry and wet spells occur, as can be seen in panels (a) and (b) for the Indian subcontinent and northern parts of Southeast Asia. The climatology shows a duration of six to nine months for dry spells and mostly two to three months and partly up to four months for maximum wet spell durations. The orography influences the spell duration, for example at the Western Ghat mountains of India, where maximum wet spells can endure longer than in the rest of India. The same monsoon characteristic also appears for northern Australia and the surrounding Pacific ocean. For the southern part of Southeast Asia near the equator, the perennial convective ITCZ zone can be identified by the long wet spell duration of up to four months and shorter dry periods over land and over ocean. The consecutive dry day climatology also shows expected large values for the dry regions of the Gobi desert, southern Pakistan, and Afghanistan. Panel (c) shows the very heavy precipitation index r20. This index emphasizes the orographic induced precipitation distribution. In mountainous regions, the number of days with heavy precipitation reaches values up to 90 days per year on average. The same goes for the west coast of Southeast Asia, while the number of days is smaller for the remaining areas and even smaller on the lee side of the mountains. We also find large numbers of days with heavy precipitation over land in the equatorial zone, where numbers also go up to 90 days per year on average. An increased index value can further be seen on the Indian ocean west of the Sumatra island and along the equatorial pacific. Another feature is the region around Taiwan, Japan and the neighboring Pacific ocean, where the structure of increased index values allows to see paths of tropical storm systems and typhoons that occur there. In dry regions, such as the Gobi desert, the index values drop down to one day per year or less on average. Panel (d) shows the sdii. The distribution of extreme values is similar to that of the heavy precipitation index. We find maximum values at the luff of mountainous regions, and smaller values for the rest. They can reach up to more than $30 \mathrm{~mm} \cdot \mathrm{d}^{-1}$. One pixel indicates the Cherrapunjee location with its extraordinary annual precipitation amount of more than $11,000 \mathrm{~mm}$. The precipitation amount on wet days lies between 27 and $30 \mathrm{~mm} \cdot \mathrm{d}^{-1}$. The SDII values in the equatorial region are smaller than in the monsoon region. Values between 8 and $15 \mathrm{~mm} \cdot \mathrm{d}^{-1}$ are reached there. For the already discussed tropical storm region between Taiwan and Japan along the Ryukyu islands, the SDII shows increased values of up to $24 \mathrm{~mm} \cdot \mathrm{d}^{-1}$, corresponding to other indices. In the dry areas, the SDII shows values of less than $2 \mathrm{~mm} \cdot \mathrm{d}^{-1}$. 


\section{DAPACLIP ETCCDI Climatology}
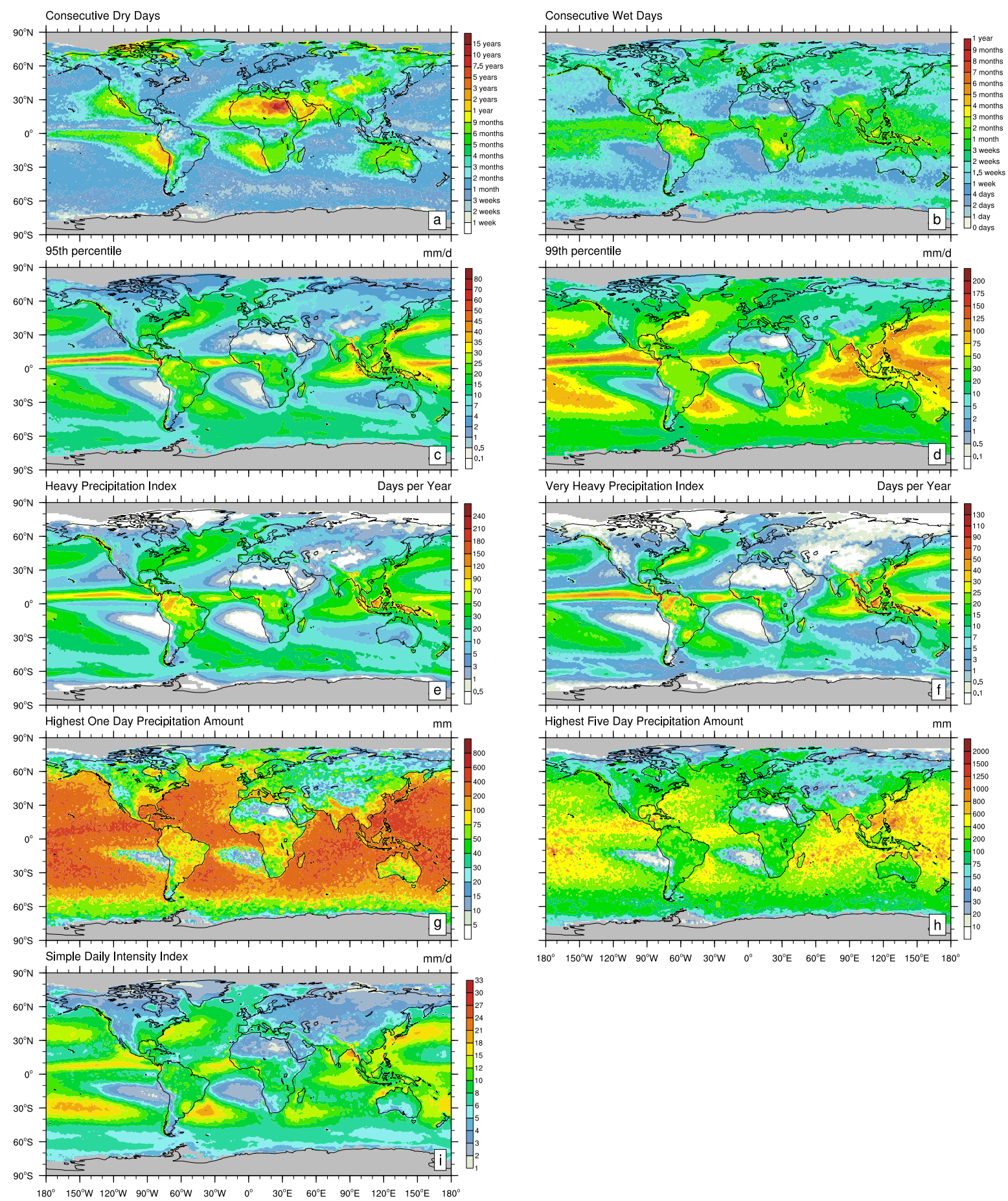

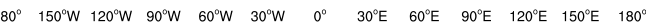

Figure 5. DAPACLIP ETCCDI climatology for the period 1988-2008 for all indices listed in Table 1. Panel (a): consecutive dry days (cdd). Panel (b): consecutive wet days (cwd). Panel (c): 95th percentile of precipitation (r95p). Panel (d): 99th percentile of precipitation (r99p). Panel (e): Heavy precipitation index (r10). Panel (f): Very heavy precipitation index (r20). Panel (g): Maximum one day precipitation (rx1). Panel (h): Maximum five day precipitation (rx5). Panel (i): Simple daily intensity index (sdii). 


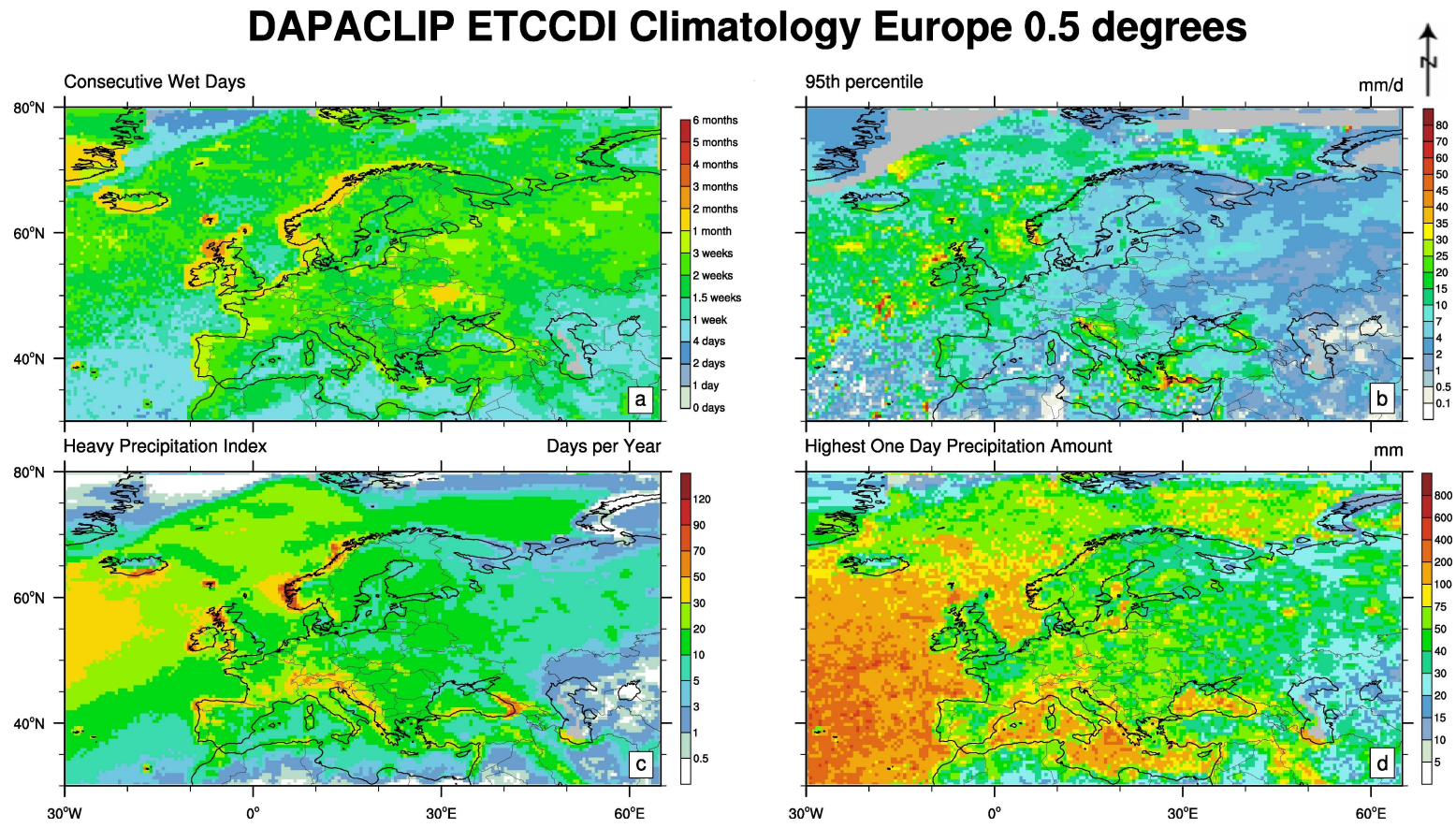

Figure 6. DAPACLIP ETCCDI climatology for the period 1988-2008 for Europe in $0.5^{\circ}$ spatial resolution for selected ETCCDI indices. Panel (a): cwd index. Panel (b): r95p index. Panel (c): r10 index. Panel (d): rx1 index.

\section{DAPACLIP ETCCDI Climatology Monsoon Asia}
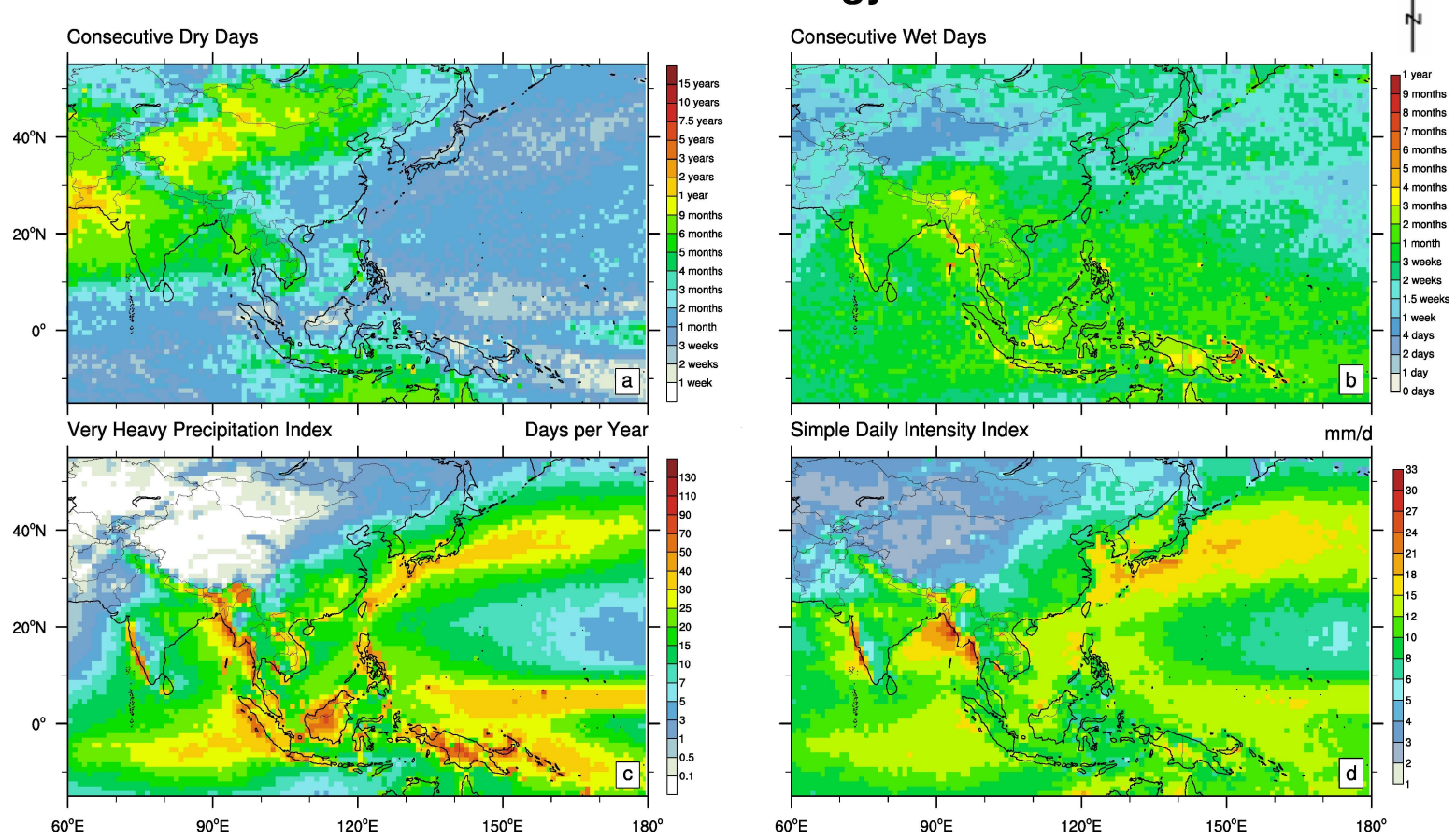

Figure 7. DAPACLIP ETCCDI climatology for the period 1988-2008 for the region of Monsoon Asia in $1.0^{\circ}$ spatial resolution for selected ETCCDI indices. Panel (a): cdd index. Panel (b): cwd index. Panel (c): r20 index. Panel (d): sdii index. 


\section{Summary and Discussion}

The presented DAPACLIP dataset and the ETCCDI climatology are based on a combination of two separate data sources. Gauge-based GPCC data are used as the precipitation data source over land, and satellite-based data from the HOAPS dataset are used over ocean surfaces. The dataset spans a time range of 21 years from 1988-2008. Three different spatial resolutions are provided: $1^{\circ}$ and $2.5^{\circ}$ for the global scale and $0.5^{\circ}$ for the European domain. Uncertainty measures are also featured within the dataset. The datasets are provided under a digital object identifier (DOI) reference [25-27]. The DAPACLIP dataset is currently used for the hindcast-based evaluation of the MiKlip decadal forecast system and it has been developed for this purpose in the first place. ETCCDI indices were used for the forecast system evaluation and they allowed for the comparison of statistical and climatological features and their representation in the respective decadal model hindcasts.

In addition, ETCCDI was also used as the basis for the generation of a global precipitation climatology. Nine different indices were examined and a climatology for the whole 21 years (i.e., the DAPACLIP dataset temporal coverage) has been presented for the global scale in general and for the European and the Monsoon Asia region for more details. The climatology is based on the $1^{\circ}$ version of DAPACLIP and is available on request. It shows different climatological features such as tropical storm paths, orographic effects, and monsoon. While climatological large scale features are well reproduced, there are some limitations for small scale features in some regions. There are various reasons for this that will be discussed further.

The density of gauge stations is occasionally sparse. For example, this is the case in Africa and the polar regions. The lack of available station data leads to large correlation distances for the Kriging interpolation method and corresponding uncertainties of up to $100 \%$. The gauge dataset itself features the Kriging interpolation error as shown in Figure 2, but is not included in the DAPACLIP dataset. The quality of the satellite-based data depends on the available sampling rate. Due to the diurnal distribution of satellite overpasses, not all precipitation events are likely to be detected. In DAPACLIP, the number of available satellites increases with time and so does the sampling rate. The number of available land surface gauges per grid cell varies in time, which influences the spatial sampling essentially. These issues make it difficult to derive trends from this dataset. In certain cases, this can also lead to missing extreme events or the over-representation of some individual strong events. e.g., for these reasons, the rx1 index appears noisy over ocean surfaces. Other indices are influenced by this, too.

Another issue is the interpolation on a regular grid, which leads to weakening of single extreme precipitation peaks, such as the mentioned 2002 flood in eastern Germany. Future versions of the DAPACLIP dataset will include improved uncertainty estimations, also taking into account the Kriging error. Nonetheless, the ETCCDI climatology shows reasonable results for Africa, as one would expect, but it would be useful to evaluate these results in more detail using precipitation products that are independent from GPCC.

Another source of uncertainty for both, satellite and rain gauge measurements are limited detection capabilities for extreme precipitation amounts. Several effects, such as saturation in satellite radiances or wind disturbance at gauges, hamper the exact measurement of extreme events. For these reasons, the rain rate algorithm is currently under development and the next version will be based on a physical retrieval.

\section{Outlook}

This study presented results based on the current GPCC database and satellite data derived from SSM/I and TMI observations. It is planned to include additional gauge-based data with improved quality control to enhance the spatial coverage in data void regions. The satellite sampling of HOAPS will be improved by including additional satellite data, e.g., from AMSR-E and the Global Precipitation Mission Microwave Imager (GMI).. The rain rate retrieval will be changed towards the use of a 1D-Var algorithm. This allows for the simultaneous determination of precipitation and uncertainty measures. 
More uncertainty features such as the Kriging error will be included. The DAPACLIP dataset is supposed to profit from all these enhancements.

The dataset is currently used for the evaluation of decadal climate predictions and first results from global evaluation are briefly summarized here. A core element of this evaluation is the global ETCCDI-based precipitation climatology. Comparing ETCCDI climatologies of decadal MiKlip hindcasts with this climatology exhibits well known features related to the split of the ITCZ in the eastern Pacific, likely related to biases in simulated sea surface temperatures (SST) [33,34]. It also exhibits an apparent misplacement of the ITCZ in the Pacific: the difference in the cdd index shows a strong regional maximum at the ITCZ in the MiKlip decadal hindcasts, while a strong overestimation of the cwd index is observed just north of that region.

Several other datasets are suitable for the generation of global ETCCDI-based climatologies. Comparing ETCCDI-based climatologies from various global precipitation datasets is an obvious next step and is considered here to be valuable such that consistencies and differences can be described and ideally understood.

Acknowledgments: The DAPACLIP dataset was developed within the MiKlip project framework funded by the German Federal Ministry for Education and Research (BMBF). The EUMETSAT Satellite Application Facility on Climate Monitoring is acknowledged for providing the HOAPS v3.2 data. NASA is acknowledged for providing the TMI data.

Author Contributions: Felix Dietzsch developed and analyzed the ETCCDI climatology of the DAPACLIP dataset presented herein, worked on merging the separate datasets to a final product and drafted the manuscript. Axel Andersson was responsible for the development of the satellite-based rain rate retrieval for the HOAPS dataset. Markus Ziese worked on processing the GPCC rain gauge data for the daily global precipitation dataset over land. Kerstin Schamm developed the Kriging interpolation scheme for the GPCC dataset. Kristin Raykova supported the work on the climatology with further analysis of land surface data. Marc Schröder was involved in the development of the satellite-based dataset and the generation of the DAPACLIP dataset as well as the ETCCDI climatology as supervisor and supported the drafting of the manuscript. Andreas Becker managed and supported the development process of the rain gauge dataset.

Conflicts of Interest: The authors declare no conflict of interest.

\section{References}

1. Marotzke, J.; Müller, W.A.; Vamborg, F.S.E.; Becker, P.; Cubasch, U.; Feldmann, H.; Kaspar, F.; Kottmeier, C.; Marini, C.; Polkova, I.; et al. MiKlip-A national research project on decadal climate prediction. Bull. Am. Meteor. Soc. 2016, doi:10.1175/BAMS-D-15-00184.1.

2. Adler, R.F.; Huffman, G.J.; Chang, A.; Ferraro, R.; Xie, P.-P.; Janowiak, J.; Rudolf, B.; Schneider, U.; Curtis, S.; Bolvin, D.; et al. The version-2 global precipitation climatology project (GPCP) monthly precipitation analysis (1979-present). J. Hydrometeorol. 2003, 4, 1147-1167.

3. Huffman, G.J.; Adler, R.F.; Morrissey, M.M.; Bolvin, D.T.; Curtis, S.; Joyce, R.; McGavock, B.; Susskind, J. Global precipitation at one-degree daily resolution from multisatellite observations. J. Hydrometeorol. 2001, 2, 36-50.

4. Huffman, G.J.; Adler, R.F.; Bolvin, D.T.; Gu, G. Improving the global precipitation record: GPCP Version 2.1. Geophys. Res. Lett. 2009, 36, L17808, doi:10.1029/2009GL040000.

5. Huffman, G.J.; Adler, R.F.; Bolvin, D.T.; Gu, G.; Nelkin, E.J.; Bowman, K.P.; Hong, Y.; Stocker, E.F.; Wolff, D.B. The TRMM multisatellite precipitation analysis (TMPA): Quasi-global, multiyear, combined-sensor precipitation estimates at fine scales. J. Hydrometeorol. 2007, 8, 38-55.

6. Alexander, L.V. Global observed long-term changes in temperature and precipitation extremes: A review of progress and limitations in IPCC assessments and beyond. Weather Clim. Extremes 2016, 11, 4-16.

7. Sillmann, J.; Kharin, V.V.; Zwiers, F.W.; Zhang, X.; Bronaugh, D. Climate extremes indices in the CMIP5 multimodel ensemble: Part 1. Model evaluation in the present climate. J. Geophys. Res. Atmos. 2013, 118, 1716-1733.

8. Sillmann, J.; Kharin, V.V.; Zwiers, F.W.; Zhang, X.; Bronaugh, D. Climate extremes indices in the CMIP5 multimodel ensemble: Part 2. Future climate projections. J. Geophys. Res. Atmos. 2013, 118, 2473-2493.

9. Easterling, D.R.; Kunkel, K.E.; Wehner, M.F.; Sun, L. Detection and attribution of climate extremes in the observed record. Weather Clim. Extremes 2016, 11, 17-27. 
10. Raykova, K. Trendanalysen Von Niederschlagsextremen Und Untersuchung Der Extremwertverteilung Basierend Auf Täglichen Stationsmessungen von 1988 bis 2013. Master Thesis, Goethe University Frankfurt, Frankfurt, Germany, 2016.

11. Vose, S.V.; Peterson, T.C.; Schmoyer, R.L.; Eischeid, J.K. The global historical climatology network: A preview of version 2. 75. In Proceedings of the Annual Meeting of the American Meteorological Society, Diamond Anniversary, United States of America, Dallas, TX, USA, 15-20 January 1995.

12. Klein Tank, A.M.G.; Wijngard, J.B.; Können, G.P.; Böhm, R.; Demaree, G.; Gocheva, A.; Mileta, M.; Pashiardis, S.; Hejkrlik, L.; Kern-Hansen, C.; et al. Daily dataset of 20th-century surface air temperature and precipitation series for the European Climate Assessment. Int. J. Climatol. 2002, 22, 1441-1453.

13. Schamm, K.; Ziese, M.; Becker, A.; Finger, P.; Meyer-Christoffer, A.; Schneider, U.; Schröder, M.; Stender, P. Global gridded precipitation over land: A description of the new GPCC First Guess Daily product. Earth Syst. Sci. Data 2014, 6, 49-60.

14. Willmott, C.; Rowe, C.; Philpot, W. A sensitivity analysis of some common assumptions associated with grid-point interpolation and contouring. Am. Cartogr. 1985, 12, 5-16.

15. Krige, D. Lognormal-de Wijsian Geostatistics for Ore Evolution; South African Institute of Mining and Metallurgy: Johannesburg, South Africa, 1981; pp. 23-39.

16. Shepard, D. A two-dimensional interpolation function for irregularly-spaced data. In Proceedings of the 1968 23rd ACM National Conference, New York, NY, USA, 1968; pp. 517-524, doi:10.1145/800186.810616.

17. Schneider, U.; Becker, A.; Finger, P.; Meyer-Christoffer, A.; Ziese, M.; Rudolf, B. GPCC's new land surface precipitation climatology based on quality-controlled in-situ data and its role in quantifying the global water cycle. Theor. Appl. Climatol. 2014, 115, 15-40.

18. Schneider, U.; Becker, A.; Finger, P.; Meyer-Christoffer, A.; Rudolf, B.; Ziese, M. GPCC Full Data Reanalysis Version 7.0 at $1.0^{\circ}$ : Monthly land-surface precipitation from rain-gauges built on GTS-based and historic data. Deutsch. Wetterd. 2015, doi:10.5676/DWD_GPCC/FD_M_V7_100.

19. Yamamoto, J. An alternative measure of the reliability of ordinary kriging estimates. Math. Geol. 2000, 32, 489-509.

20. The Satellite Application Facility on Climate Monitoring. Available online: http://cmsaf.eu (accessed on 21 November 2016).

21. Hamburg Ocean Atmosphere Parameters and Fluxes from Satellite Data. Available online: http://hoaps.org (accessed on 21 November 2016).

22. Andersson, A.; Fennig, K.; Klepp, C.; Bakan, S.; Grassl, H.; Schulz, J. The Hamburg Ocean atmosphere parameters and fluxes from satellite data-HOAPS-3. Earth Syst. Sci. Data 2010, 2, 215-234.

23. Fennig, K.; Andersson, A.; Bakan, S.; Klepp, C.; Schröder, M. Hamburg Ocean atmosphere parameters and fluxes from satellite data - HOAPS-3.2 - monthly means/6-hourly composites. Satell. Appl. Facil. Clim. Monit. 2012, doi:10.5676/EUM_SAF_CM/HOAPS/V001.

24. Andersson, A.; Fennig, K.; Schröder, M. Algorithm theoretical basis document HOAPS release 3.2. Satell. Appl. Facil. Clim. Monit. 2011, 1, 31-34.

25. Andersson, A.; Ziese, M.; Dietzsch, F.; Schröder, M.; Becker, A.; Schamm, K. HOAPS/GPCC European Daily Precipitation Data Record With Uncertainty Estimates Using Satellite and Gauge Based Observations at $0.5^{\circ}$. Deutscher Wetterdienst: Offenbach, Germany, 2016; doi:10.5676/DWD_CDC/HOGP_050/V001.

26. Andersson, A.; Ziese, M.; Dietzsch, F.; Schröder, M.; Becker, A.; Schamm, K. HOAPS/GPCC Global Daily Precipitation Data Record With Uncertainty Estimates Using Satellite and Gauge Based Observations at 1.0 ; Deutscher Wetterdienst: Offenbach, Germany, 2016; doi:10.5676/DWD_CDC/HOGP_100/V001.

27. Andersson, A.; Ziese, M.; Dietzsch, F.; Schröder, M.; Becker, A.; Schamm, K. HOAPS/GPCC Global Daily Precipitation Data Record With Uncertainty Estimates Using Satellite and Gauge Based Observations at 2.5 ; Deutscher Wetterdienst: Offenbach, Germany, 2016; doi:10.5676/DWD_CDC/HOGP_250/V001.

28. HOAPS/GPCC global daily precipitation data record with uncertainty estimates using satellite and gauge based observations Version 1. Available online: ftp://ftp.dwd.de/pub/data/gpcc/html/HOGP_V001.html (accessed on 19 October 2016).

29. CLIMDEX. Datesets for Indices of Climate Extremes. Available online: http://climdex.org (accessed on 26 September 2016).

30. Klein Tank, A.M.G.; Zwiers, F.W.; Zhang, X. Guidelines on Analysis of Extremes in a Changing Climate in Support of Informed Decisions for Adaptation; World Meteorological Organisation (WMO): Geneva, Switzerland, 2009. 
31. Zhang, X.; Alexander, L.; Hegerl, G.C.; Jones, P.; Klein Tank, A.M.G.; Peterson, T.C.; Trewin, B.; Zwiers, F.C. Indices for monitoring changes in extremes based on daily temperature and precipitation data. WIRES Clim. Chang. 2011, 2, 851-870.

32. Rudolf, B.; Rapp, J. Das Jahrhunderthochwasser der Elbe: Synoptische Entwicklung und klimatologische Aspekte. In Klimastatusbericht 2002; Deutscher Wetterdienst: Offenbach(Main), Germany, 2002; pp. 172-187.

33. Hazeleger, W.; Wang, X.; Severijns, C.; Ştefănescu, S.; Bintanja, R.; Sterl, A.; Wyser, K.; Semmler, T.; Yang, S.; van den Hurk, B.; et al. EC-Earth V2.2: description and validation of a new seamless earth system prediction model. Clim. Dyn. 2012, 39, 2611-2629.

34. Michael, J.-P.; Misra, V.; Chassignet, E.P. The El Niño and Southern Oscillation in the historical centennial integrations of the new generation of climate models. Reg. Environ. Chang. 2013, 13, 121-130.

(C) 2017 by the authors; licensee MDPI, Basel, Switzerland. This article is an open access article distributed under the terms and conditions of the Creative Commons Attribution (CC BY) license (http:/ / creativecommons.org/licenses/by/4.0/). 